\title{
Global Research Productivity on Calotropic sps. Over the Last Decade (2011-2020): A Bibliometric Evaluation
}

\author{
Chaman Sab M', Mallikarjun Kappi ${ }^{2}$, KK Mueen Ahmed ${ }^{3, *}$
}

\section{Chaman Sab $\mathbf{M}^{1}$, Mallikarjun Kappi KK Mueen Ahmed ${ }^{3, *}$}

'S.B.C. First Grade College for Women and Athani P.G. Centre, Davanagere, Karnataka, INDIA.

${ }^{2}$ Department of Library and Information Science, Kuvempu University, Shankaraghatta, Karnataka, INDIA ${ }^{3}$ Phcog.Net, Wheeler Road Extension, Bangalore, Karnataka, INDIA

Correspondence

\section{Dr. KK Mueen Ahmed}

Phcog.Net, Wheeler Road Extension, Bangalore, Karnataka, INDIA.

Phone no: +91-9686454568

Email id: mueen.ahmed@gmail.com

History

- Submission Date: 05-05-2021;

- Review completed: 25-05-2021;

- Accepted Date: 06-06-2021

DOI : 10.5530/pres.13.3.2

Article Available online

http://www.phcogres.com

\section{Copyright}

(C) 2021 Phcog.Net. This is an openaccess article distributed under the terms of the Creative Commons Attribution 4.0 International license.

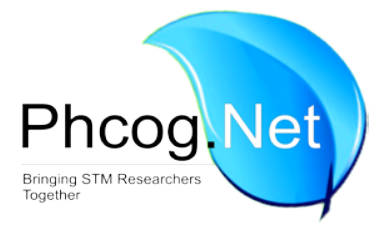

\begin{abstract}
Aim: In this study, we performed a bibliometric analysis focusing on the general patterns of scientific publications about Calotropis, bibliometric analysis of Calotropis research carried out globally from 2011 to 2020. Materials and Methods: The analysis is based on 6,584 research articles identified using the Scopus database tool, further Bibliometric tools such as Biblioshiny and VOSviewer have been used to perform bibliometric analysis and build data matrixes for co-citation, coupling, scientific collaboration analysis, and co-word analysis. Results: The results show that there is an increase in the number of articles, particularly from countries like India and China. Ramos, Márcio Viana and Rahmatullah, Mohammed are identified as the most influential authors, and King Saud University, Saudi Arabia and Universidade Federal do Ceara, Brazil as key organisations. "Methods for in vitro evaluating antimicrobial activity: A review" this paper total of 1679 citations are received. Total of 105 articles published during this period are highly cited. Journal of Ethnopharmacology and International Journal of Pharmacy and Pharmaceutical Sciences are the important journals identified. The most common area of the research focus has been on the most common area of the research focus has been on the Agricultural and Biological Sciences, Pharmacology, Toxicology and Pharmaceutics, Biochemistry, Genetics, and Molecular Biology and Medicine. Findings: Our findings can act as a useful reference for researchers, and provide insights for directing future research on Calotropis that has potential implications for forming across the world.
\end{abstract}

Keywords: Calotropis, Bibliometric evaluation, Scopus database, International collaboration.

\section{INTRODUCTION}

The term of therapeutic plants incorporate a different sorts of plants utilized in herbalism and a portion of these plants have a restorative exercises. These restorative plants consider as a rich assets of fixings which can be utilized in drug advancement and blend. Other than that these plants assume a basic part in the advancement of human societies around the entire world. Additionally, a few plants consider as significant wellspring of sustenance and because of that these plants suggested for their helpful qualities. These plants incorporate ginger, green tea, pecans and some others plants. Different plants their subsidiaries consider as significant hotspot for dynamic fixings. ${ }^{[1]}$

Nowadays the term Alternative Medicine turned out to be normal in western culture, it centre on utilizing the plants for restorative reason. However, the current conviction that meds which come in containers or pills are the solitary drugs that we can trust and utilize. Indeed, even so the greater part of these pills and containers we take and use during our day by day life came from plants. Therapeutic plants oftentimes utilized as crude materials for extraction of dynamic fixings which utilized in the union of various medications. Like in the event of intestinal medicines, blood thinners, anti-infection agents and antimalaria prescriptions, contain fixings from plants. ${ }^{[2]}$

Calotropis is a genus of flowering plants in the family Apocynaceae, first described as a genus in 1810 . Calotropis procera is a native plant of North Africa referred as a tropical plant growing of about 1050 meters. Particularly it prefers the warm climate so it's distributed is maximum in Rajasthan ${ }^{[3]}$ Calotropis procera properly grows in dry and open habitat found along road-side, dry land of rural and urban region where soil is excessively drained and xerophytic conditions are available. It established very rapidly because it tolerates a high degree of abiotic stresses such as drought, salinity, temperature etc and dominating the arid zones where annual precipitation is very low. ${ }^{[4]}$ The number of ethanomedicinal uses of calotropis are mentioned in Ayurveda and popularly known as Raktha Arka. Traditionally it was used as an excellent substitute for ipecac, to treat cholera, elephantiasis diarrhea dysentery indigestion and used in extracting guinea worms. ${ }^{[5]}$

Calotropis procera contained many biological active chemical groups including, cardenolides, steroids, tannins, glycosides, phenols, terpenoids, sugars, flavonoids, alkaloids and saponins. It exerted many

Cite this article: Chaman SM, Kappi M, Ahmed KKM. Global Research Productivity on Calotropic sps. over the last Decade (2011 - 2020): A Bibliometric Evaluation. Pharmacog Res. 2021;13(3):113-20. 
pharmacological effects such as antimicrobial, anthelmintic, antiinflammatory, analgesic and antipyretic, anticancer activities. Traditionally it was used to treat cholera, extracting guinea worms and indigestion ${ }^{\cdot[6]}$

Calotropis procera is a well-known cure in Ayurvedic and conventional time for the treatment of a scope of sicknesses. The phytochemicals of this plant should be normalized to investigate its therapeutic qualities with the assistance of different strategies. Further exploration is important to explain the phytochemical also, pharmacological parts of this plant. The presence of a number of phytoconstituents and pharmacological activities of Calotropis procerea is an expected hotspot for the turn of events of new medications to drug industry. ${ }^{[4]}$

\section{RELATED LITERATURE}

Several studies have looked at publication patterns in the context of subject-wise research output. ${ }^{[7]}$ Bibliometric study conducted on the Celastrus paniculatus plant is presented based on selected quantitative and qualitative indicators, using Scopus international database during 2001-18 of global research output. The study analysed publication and citations, growth rate, citations impact, international collaborative papers, most productive countries, organizations, authors, journals and highly cited papers ${ }^{[8]}$ Studied the Scientometric study on Glycyrrhiza glabra world research output using the Scopus database during 1997-2016. Study covers the growth rate, global share, citation impact, and international collaboration, distribution of publications and citation pattern and high cited papers. ${ }^{[9]}$ Conducted Quantitative and Qualitative study of Global Research on Terminalia arjuna Publications during 2004-2018 using Scopus database. ${ }^{[10-15]}$ Done various medicinal plant research publications assessment using the scientometrics / bibliometrics indicators. All the studies were used the Scopus database in various time durations.

\section{OBJECTIVES}

The main objectives of this study performance of Calotropis research output during the study period 2011 - 2020, based on publications output covered in Scopus database. In particular, the study focuses on the following objectives: (i) To study the growth of world research output in Calotropis research and its citation impact. (ii) To study the top 20 most productive countries (iii) To study the most productive subject areas. (iv) To study the highly productive organisations and citation impact. (v) To study the forms for communication. (vi) To study the top most productive authors and citation impact (vii) To identify the highly cited publications (viii) To study the most preferred sources (vii) To study the most used keywords.

\section{METHODOLOGY}

Scientific publications related to Calotropis released from 2011 to 2020, were retrieved from the Scopus ${ }^{\oplus}$ (http://www.scopus.com) in May 2021. Scopus is a global multidisciplinary database with larger coverage compared to other online platforms such as Web of Science and the Scientific Electronic Library Online. Currently, it covers about 15,000 international peer-reviewed journals in the field of science and technology data $^{[16]}$ The study retrieved and downloaded ten years data of the world Calotropis research from the Scopus database during the study period 2011 - 2020. Keywords, such as "Calotropis" ALL (Calotropis) AND PUBYEAR > 2010 AND PUBYEAR < 2021. The search string was subsequently refined, using analytical functions and tags in Scopus database, by "year wise tag", "country tag", source title tag", "collaborating countries", "author-wise", "organisation-wise" and "keywords" etc. For citing data, citations to publications were also collected from data of publications till date 25 May 2021.

\begin{tabular}{|c|c|}
\hline Description & Results \\
\hline \multicolumn{2}{|c|}{ MAIN INFORMATION ABOUT DATA } \\
\hline Timespan & 2011:2020 \\
\hline Sources (Journals, Books, etc) & 2055 \\
\hline Documents & 6584 \\
\hline Average years from publication & 4.6 \\
\hline Average citations per documents & 13.33 \\
\hline Average citations per year per doc & 2.347 \\
\hline References & 1 \\
\hline \multicolumn{2}{|l|}{ DOCUMENT TYPES } \\
\hline article & 5512 \\
\hline article in press & 2 \\
\hline book & 25 \\
\hline book chapter & 223 \\
\hline conference paper & 150 \\
\hline conference review & 1 \\
\hline data paper & 3 \\
\hline editorial & 11 \\
\hline erratum & 2 \\
\hline letter & 8 \\
\hline note & 2 \\
\hline retracted & 4 \\
\hline review & 634 \\
\hline short survey & 7 \\
\hline \multicolumn{2}{|l|}{ DOCUMENT CONTENTS } \\
\hline Keywords Plus (ID) & 32421 \\
\hline Author's Keywords (DE) & 15434 \\
\hline \multicolumn{2}{|l|}{ AUTHORS } \\
\hline Authors & 21355 \\
\hline Author Appearances & 31073 \\
\hline Authors of single-authored documents & 234 \\
\hline Authors of multi-authored documents & 21121 \\
\hline \multicolumn{2}{|l|}{ AUTHORS COLLABORATION } \\
\hline Single-authored documents & 263 \\
\hline Documents per Author & 0.308 \\
\hline Authors per Document & 3.24 \\
\hline Co-Authors per Documents & 4.72 \\
\hline Collaboration Index & 3.34 \\
\hline
\end{tabular}

\section{ANALYSIS}

\section{Annual Growth of World Calotropis research output}

Table 2 and Figure 1 highlights the annual growth of world Calotropis research distribution of publications, mean TCPA and TCPY received for Calotropis research. Total of 6,584 papers were published, and is found that most productive year in terms of publication count is 2020 with 1194 publications and 1421 citations, followed by 961 publications with 13 citations received in 2019. Lowest citations were received in the year 2019, followed by, which were published during 2013. Lowest numbers of articles i.e. 433 were published in the year 2011. (Table 1) 
Sab, et al.: Bibiolmetric Analysis of Calotropis sps.

Table 1: Year wise distribution of publications.

\begin{tabular}{ccccc}
\hline Year & Publications & TC & Mean TCPA & Mean TCPY \\
\hline 2011 & 433 & 189 & 22.42 & 2.24 \\
2012 & 473 & 291 & 19.84 & 2.20 \\
2013 & 475 & 139 & 20.31 & 2.54 \\
2014 & 558 & 246 & 17.89 & 2.56 \\
2015 & 527 & 250 & 15.99 & 2.67 \\
2016 & 554 & 451 & 21.86 & 4.37 \\
2017 & 697 & 502 & 14.52 & 3.63 \\
2018 & 712 & 441 & 11.32 & 3.77 \\
2019 & 961 & 13 & 6.90 & 3.45 \\
2020 & 1194 & 1471 & 3.08 & 3.08 \\
\hline
\end{tabular}

$\mathrm{TC}=$ Total Citations, $\mathrm{TCPA}=$ Total Citations per Article, $\mathrm{TCPY}=$ Total Citations per Year

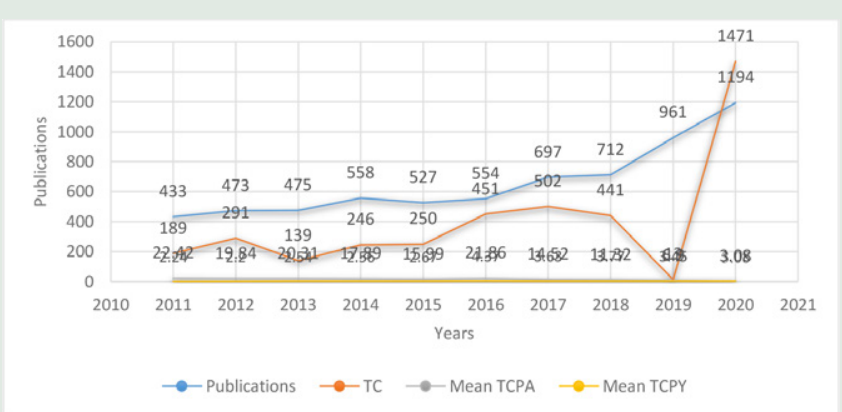

Figure 1: Year wise distribution of publications.

\section{Top 20 most productive countries in Calotropis research}

A total of 134 countries/ regions contributed to the 6584 publications during the period $2011-2020$. The international share of articles ${ }^{[17]}$ is presented in the Table 2, which gives the country wise-distribution of contributions. Out of total 6584 research publications, India contributed the highest number of research articles contributing 2445 publications (TC-8255, HI: 105) with (37.13\%) share, followed by China contributed 696 publications (TC-2816, HI:39) with (10.57\%) share, Brazil contributed 556 publication (TC-1517, HI:30) with (8.44\%) Pakistan contributed 479 publications (TC-1769, HI:39) with (7.25\%) share, Saudi Arabia Contributed 399 publication (TC-1352, HI:29) with (6.06\%) share. The table and Figure 2 shows the top 20 productive countries ones

\section{Subject-Wise Distribution of Research output}

Publication rates and citation behaviour can vary considerably from one research area to another, and this is the reason we usually discuss the performance of papers within the same research area. ${ }^{[18]}$ In this study, initially, we collected all the published research papers discussed here from the research field of Calotropis based on a broader scheme compressing 20 research areas out of 27 . However, we have examined these Calotropis papers using the Scopus database. Table 3 shows the global Calotropis research output published during $2011-2020$ is distributed across 20 sub-fields, with Agricultural and Biological Sciences according for the highest publications share (30.01\%), followed by Pharmacology, Toxicology and Pharmaceutics (25.24\%), Biochemistry, Genetics and Molecular Biology (23.26\%), Medicine (18.33\%), Chemistry (13.79\%), Environmental Science (12.22\%), Materials Science (11.92\%) and
Table 2: Top 20 countries/regions in Calotropis research.

\begin{tabular}{|c|c|c|c|c|c|c|c|c|}
\hline \multirow{2}{*}{$\begin{array}{l}\text { Name of } \\
\text { the Country }\end{array}$} & \multicolumn{3}{|c|}{ Number of papers } & \multicolumn{3}{|c|}{ Share of papers } & \multirow[t]{2}{*}{ TC } & \multirow{2}{*}{$\begin{array}{c}H \\
\text { inder }\end{array}$} \\
\hline & $\begin{array}{l}2011- \\
2015\end{array}$ & $\begin{array}{l}2016- \\
2020\end{array}$ & $\begin{array}{c}2011- \\
2020\end{array}$ & $\begin{array}{l}2011- \\
2015\end{array}$ & $\begin{array}{l}2016- \\
2020\end{array}$ & $\begin{array}{c}2011- \\
2020\end{array}$ & & \\
\hline India & 1093 & 1352 & 2445 & 16.6 & 20.53 & 37.13 & 8255 & 105 \\
\hline China & 157 & 539 & 696 & 2.38 & 8.18 & 10.57 & 2816 & 39 \\
\hline Brazil & 203 & 353 & 556 & 3.08 & 5.34 & 8.44 & 1517 & 30 \\
\hline Pakistan & 160 & 319 & 479 & 2.43 & 4.84 & 7.25 & 1769 & 39 \\
\hline Saudi Arabia & 105 & 294 & 399 & 1.54 & 4.46 & 6.06 & 1352 & 29 \\
\hline Egypt & 112 & 266 & 378 & 1.7 & 4.04 & 5.74 & 1083 & 28 \\
\hline United States & 102 & 184 & 286 & 1.54 & 2.79 & 4.34 & 2105 & 39 \\
\hline Iran & 66 & 199 & 265 & 1 & 3.02 & 4.02 & 1018 & 28 \\
\hline Malaysia & 71 & 131 & 202 & 1.07 & 1.9 & 3.06 & 1080 & 31 \\
\hline South Korea & 50 & 133 & 183 & 0.75 & 2.02 & 2.77 & 1504 & 38 \\
\hline Nigeria & 77 & 102 & 179 & 1.16 & 1.54 & 2.71 & 1822 & 40 \\
\hline Indonesia & 14 & 108 & 122 & 0.21 & 1.64 & 1.85 & 178 & 11 \\
\hline Bangladesh & 78 & 41 & 119 & 1.18 & 0.62 & 3.02 & 246 & 19 \\
\hline Germany & 34 & 75 & 109 & 0.51 & 1.13 & 1.65 & 647 & 25 \\
\hline South Africa & 19 & 84 & 103 & 0.28 & 1.27 & 1.56 & 588 & 20 \\
\hline Italy & 24 & 75 & 99 & 0.36 & 1.13 & 1.5 & 796 & 26 \\
\hline Australia & 35 & 61 & 96 & 0.53 & 0.92 & 1.45 & 489 & 21 \\
\hline Japan & 30 & 58 & 88 & 0.45 & 0.88 & 1.33 & 260 & 18 \\
\hline Thailand & 20 & 66 & 86 & 0.3 & 1 & 1.3 & 442 & 19 \\
\hline Turkey & 33 & 51 & 84 & 0.5 & 0.77 & 1.27 & 225 & 17 \\
\hline Total & 2483 & 4491 & 6974 & 37.57 & 68.02 & 107.02 & 28192 & \\
\hline
\end{tabular}

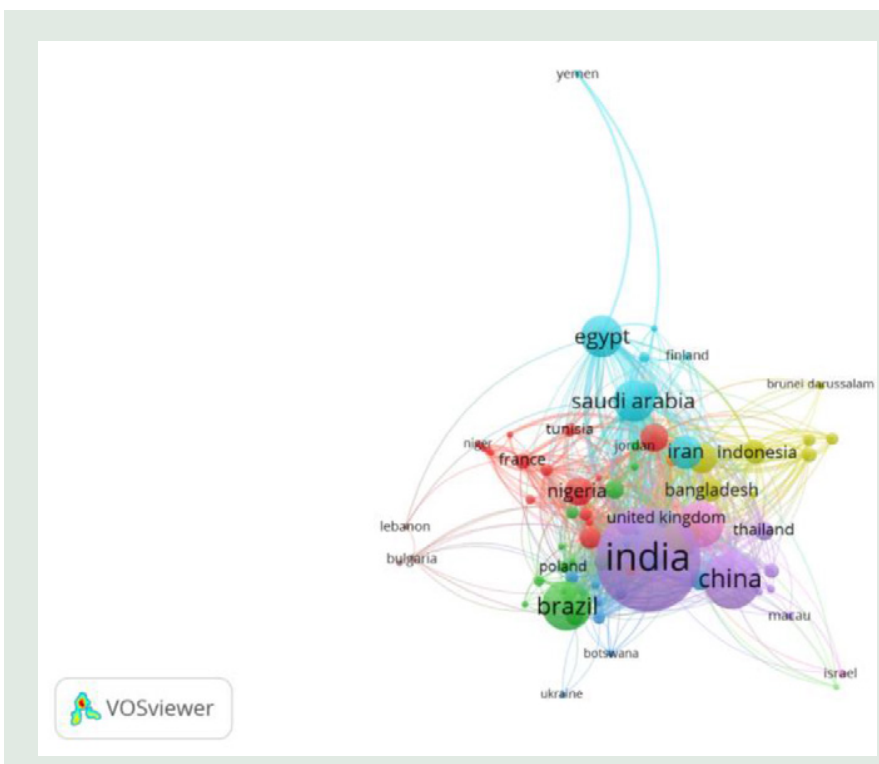

Figure 2: Top 20 countries/regions in Calotropis research.

remaining all sub fields have below $10 \%$ publications share. Biochemistry, Genetics and Molecular Biology among various subjects registered the highest citations impact per paper of $23.26 \mathrm{ACP}$ with 6352 citations, followed by Chemistry 13.79 ACP with 5254 Citations, and lowest citations from nursing subject with 83 citations during the period of study Table 3. 
Table 3: Subject-wise distribution of Calotropis research.

\begin{tabular}{ccccc}
\hline SN & Subject & TP & TC & ACP \\
\hline 1 & Agricultural and Biological Sciences & 1976 & 4694 & 30.01 \\
2 & Pharmacology, Toxicology and & 1662 & 4723 & 25.24 \\
& Pharmaceutics & & & \\
3 & Biochemistry, Genetics and Molecular & 1532 & 6352 & 23.26 \\
& Biology & & & \\
4 & Medicine & 1207 & 3803 & 18.33 \\
5 & Chemistry & 908 & 5254 & 13.79 \\
6 & Environmental Science & 805 & 3264 & 12.22 \\
7 & Materials Science & 785 & 4078 & 11.92 \\
8 & Engineering & 586 & 2709 & 8.90 \\
9 & Chemical Engineering & 584 & 3285 & 8.86 \\
10 & Immunology and Microbiology & 417 & 2185 & 6.33 \\
11 & Physics and Astronomy & 354 & 4198 & 5.37 \\
12 & Energy & 190 & 3087 & 2.88 \\
13 & Multidisciplinary & 157 & 2932 & 2.38 \\
14 & Veterinary & 138 & 2290 & 2.09 \\
15 & Earth and Planetary Sciences & 109 & 2362 & 1.65 \\
16 & Economics, Econometrics and Finance & 69 & 2513 & 1.04 \\
17 & Computer Science & 61 & 2337 & 0.92 \\
18 & Health Professions & 55 & 768 & 0.83 \\
19 & Social Sciences & 44 & 60 & 0.66 \\
20 & Nursing & 38 & 83 & 0.57 \\
\hline & & &
\end{tabular}

\section{Top 20 most productive global organisations}

We have identified 168 organisations and the 20 most productive ones are shown in Table 4 and Figure 3, including 4 from Saudi Arabia, Brazil, Pakistan, 3 from India, Egypt and 2 from China. The large portion of Saudi Arabia organisations, 4 out of 20, indicates the country's leading role in high-level scientific research in Calotropis There are only 5 organisations from the other top 15 countries suggesting that the Calstopis researches conducted worldwide are relatively concentrated in several top organisations. King Saud University, Saudi Arabia is the most productive organisation which contributed 163 (28.00\%) publications with the highest citations, Universidade Federal do Ceara, Brazil ranks the second with 106 (35.69\%) publications and 297 citations, followed by King Abdulaziz University, Saudi Arabia produced 96 (30.67\%) publication with 313 citations, Ministry of Education China produced 93 (25.20\%) publications with 369 citations.

Further analysis shows that there are 148 organisations owning at least 90 publications and Figure 3 gives their collaboration network.

\section{Medium of Research communication}

Table 5 shows that $83.72 \%$ (5512) global publications on Calotropis publications appeared in articles and the rest as Reviews 634 (9.63\%), Book Chapters 223 (3.39\%), Conference papers 150 (2.28\%), Books $25(0.38 \%)$, Editorials $11(0.17 \%)$, remaining all below 10 papers each share their papers.

\section{Top 20 most productive authors}

The research productivity in the field of Calotropis research of top 20 most productive authors varied from 25.25\% (420) global publication share and 40\% (1663) citations share during 2011 - 2020. Table 3 six author's registered publications output above the group average of 2.96:
Table 4: Characteristics of the top 20 organisations in Calotropis.

\begin{tabular}{|c|c|c|c|c|c|c|}
\hline SN & $\begin{array}{l}\text { Name of the } \\
\text { Organisation }\end{array}$ & Country & TP & TC & ACP & $\begin{array}{c}H \\
\text { index }\end{array}$ \\
\hline 1 & King Saud University & $\begin{array}{l}\text { Saudi } \\
\text { Arabia }\end{array}$ & 163 & 582 & 28.000 & 23 \\
\hline 2 & $\begin{array}{l}\text { Universidade Federal do } \\
\text { Ceara }\end{array}$ & Brazil & 106 & 297 & 35.69 & 20 \\
\hline 3 & King Abdulaziz University & $\begin{array}{l}\text { Saudi } \\
\text { Arabia }\end{array}$ & 96 & 313 & 30.67 & 16 \\
\hline 4 & $\begin{array}{l}\text { Ministry of Education } \\
\text { China }\end{array}$ & China & 93 & 369 & 25.20 & 16 \\
\hline 5 & $\begin{array}{l}\text { Chinese Academy of } \\
\text { Sciences }\end{array}$ & China & 87 & 426 & 20.42 & 20 \\
\hline 6 & Quaid-i-Azam University & Pakistan & 73 & 410 & 17.80 & 23 \\
\hline 7 & $\begin{array}{l}\text { Vellore Institute of } \\
\text { Technology }\end{array}$ & India & 70 & 290 & 24.13 & 18 \\
\hline 8 & $\begin{array}{c}\text { University of Agriculture, } \\
\text { Faisalabad }\end{array}$ & Pakistan & 66 & 159 & 41.50 & 18 \\
\hline 9 & $\begin{array}{l}\text { King Saud University } \\
\text { College of Science }\end{array}$ & $\begin{array}{l}\text { Saudi } \\
\text { Arabia }\end{array}$ & 64 & 321 & 19.93 & 18 \\
\hline 10 & National Research Centre & Egypt & 63 & 119 & 52.94 & 13 \\
\hline 11 & $\begin{array}{l}\text { Universidade Federal } \\
\text { Rural de Pernambuco }\end{array}$ & Brazil & 52 & 97 & 53.60 & 12 \\
\hline 12 & $\begin{array}{l}\text { Government College } \\
\text { University Faisalabad }\end{array}$ & Pakistan & 52 & 208 & 25 & 16 \\
\hline 13 & $\begin{array}{l}\text { University of the Punjab, } \\
\text { Lahore }\end{array}$ & Pakistan & 51 & 272 & 18.75 & 14 \\
\hline 14 & $\begin{array}{c}\text { Universidade de Sao Paulo } \\
\text { - USP }\end{array}$ & Brazil & 50 & 172 & 29.06 & 16 \\
\hline 15 & Assiut University & Egypt & 48 & 133 & 36.09 & 13 \\
\hline 16 & Annamalai University & India & 47 & 192 & 24.47 & 15 \\
\hline 17 & $\begin{array}{l}\text { Universidade Federal } \\
\text { Rural do Semi-Arido }\end{array}$ & Brazil & 47 & 61 & 77.04 & 8 \\
\hline 18 & Al-Azhar University & Egypt & 44 & 114 & 38.59 & 11 \\
\hline 19 & Bharathiar University & India & 44 & 177 & 24.85 & 17 \\
\hline 20 & $\begin{array}{l}\text { King Saud University } \\
\text { College of Pharmacy }\end{array}$ & $\begin{array}{l}\text { Saudi } \\
\text { Arabia }\end{array}$ & 43 & 83 & 51.80 & 9 \\
\hline
\end{tabular}

TP: Total Paper, TC: Total Citation, ACP: Average citations per paper, HI: $h$-Index.

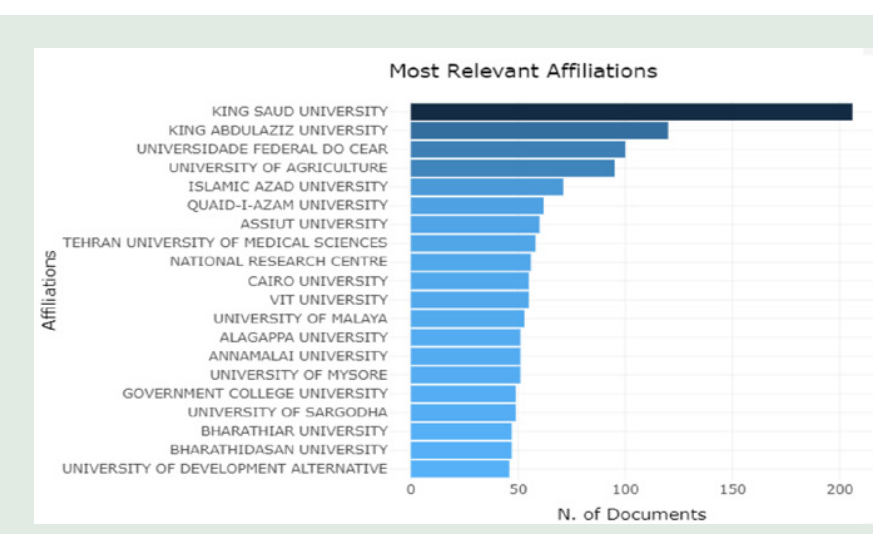

Figure 3: Top 20 most productive Institutions/organisations in Calotropis research. 
Ramos, Márcio Viana published 63 (0.95\%) papers, 188 citations with $16 \mathrm{~h}$-index, followed by Rahmatullah, Mohammed published 39 (0.59\%) papers, 25 citations with $8 h$-index, Freitas, C.D.T. published $26(0.39 \%)$ papers 95 citations with 10- $h$ index, Neto, Francisco Bezerra published $25(0.37 \%)$ papers, 35 citations with $8 h$-index, Ayodhya, Dasari,

\section{Table 5: Medium of research communication in Calotropis.}

\begin{tabular}{cccc}
\hline SN & Document type & TP & $6584 \%$ \\
\hline 1 & Article & 5512 & 83.72 \\
2 & Review & 634 & 9.63 \\
3 & Book Chapter & 223 & 3.39 \\
4 & Conference Paper & 150 & 2.28 \\
5 & Book & 25 & 0.38 \\
6 & Editorial & 11 & 0.17 \\
7 & Letter & 8 & 0.12 \\
8 & Short Survey & 7 & 0.11 \\
9 & Retracted & 4 & 0.06 \\
10 & Data Paper & 3 & 0.05 \\
11 & Erratum & 2 & 0.03 \\
12 & Note & 2 & 0.03 \\
13 & Conference Review & 1 & 0.02 \\
14 & Undefined & 2 & 0.03 \\
& & 6584 & 100.00 \\
\hline
\end{tabular}

Nagabhushana, H., published 21 (0.31\%) papers, Sharma, S. C., Veerabhadram, Guttena, Zheng, Yian ,published 19 (0.28\%) papers (Figure 4).

\section{Highly cited papers}

Highly cited papers are important to the reputations of the university. ${ }^{[19]}$ Table 7 and Figure 5 shows the highly cited papers published in the field of Calotropis research publication published in different journals. Most of the papers/authors from Agricultural and Biological Sciences and Pharmacology, Toxicology and Pharmaceutics filed. Interestingly, all the highly cited papers are published in journals and the papers that have received 357 citations and these papers received $9180(3.88 \%)$ of all

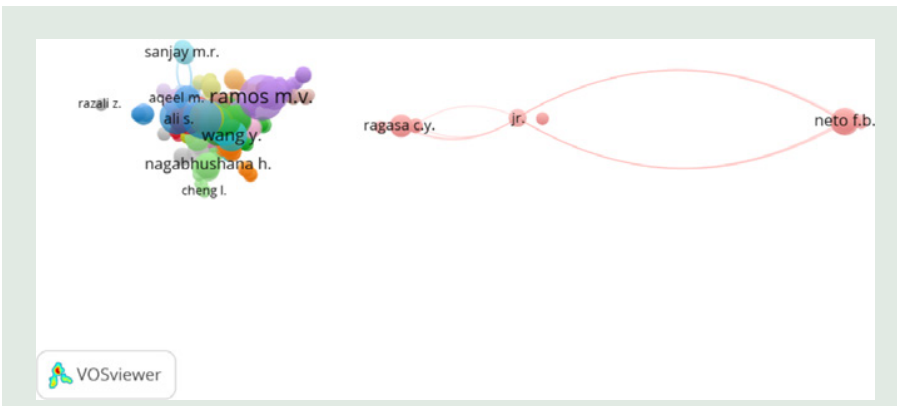

Figure 4: Co-authors network.

Table 6: Top 20 most productive and most impactful authors in Calotropis research during 2011 - 2020.

\begin{tabular}{|c|c|c|c|c|c|c|c|c|}
\hline & SN & Author & Author Affiliation & TP & ACP & TC & ACP & $\mathrm{HI}$ \\
\hline \multirow{20}{*}{ 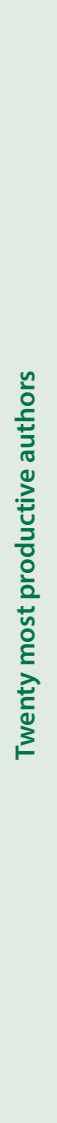 } & 1 & Ramos, Márcio Viana & Universidade Federal do Ceara, Fortaleza, Brazil & 63 & 0.95 & 188 & 0.95 & 16 \\
\hline & 2 & Rahmatullah, Mohammed & University of Development Alternative, Dhaka, Bangladesh & 39 & 0.59 & 25 & 0.59 & 8 \\
\hline & 3 & Freitas, C.D.T. & Universidade Federal do Ceara, Fortaleza, Brazil & 26 & 0.39 & 95 & 0.39 & 10 \\
\hline & 4 & Neto, Francisco Bezerra & Universidade Federal Rural do Semi-Arido, Mossoro, Brazil & 25 & 0.37 & 35 & 0.37 & 8 \\
\hline & 5 & Ayodhya, Dasari & Osmania University, Hyderabad, India & 21 & 0.31 & 103 & 0.31 & 10 \\
\hline & 6 & Nagabhushana, H. & Tumkur University, Tumkur, India & 21 & 0.31 & 121 & 0.31 & 14 \\
\hline & 7 & Sharma, S. C. & Indian Institute of Technology Guwahati, Guwahati, India & 19 & 0.28 & 98 & 0.28 & 13 \\
\hline & 8 & Veerabhadram, Guttena & Osmania University, Hyderabad, India & 19 & 0.28 & 98 & 0.28 & 9 \\
\hline & 9 & Zheng, Yian & Lanzhou University, Lanzhou, China & 19 & 0.28 & 119 & 0.28 & 11 \\
\hline & 10 & Mukhtar, Tariq & PMAS-Arid Agriculture Univerity Rawalpindi, Pakistan & 16 & 0.24 & 115 & 0.24 & 16 \\
\hline & 11 & Murugan, Kadarkarai & Bharathiar University, Coimbatore, India & 16 & 0.24 & 122 & 0.24 & 13 \\
\hline & 12 & Shinwari, Zabta Khan & Quaid-i-Azam University, Islamabad, Pakistan & 16 & 0.24 & 95 & 0.24 & 9 \\
\hline & 13 & Ullah, Riaz & King Saud University College of Pharmacy, Riyadh, Saudi Arabia & 16 & 0.24 & 50 & 0.24 & 7 \\
\hline & 14 & Anantharaju, K. S. & Dayananda Sagar College of Engineering, Bengaluru, India & 15 & 0.22 & 71 & 0.22 & 11 \\
\hline & 15 & Diederich, Marc & Seoul National University, Seoul, South Korea & 15 & 0.22 & 110 & 0.22 & 12 \\
\hline & 16 & Maaza, Maalik M. & University of South Africa, Pretoria, South Africa & 15 & 0.22 & 152 & 0.22 & 9 \\
\hline & 17 & Mohamed, Gamal Abdalla & Al-Azhar University, Nasr City, Egypt & 15 & 0.22 & 20 & 0.22 & 6 \\
\hline & 18 & Ragasa, CY & De La Salle University-Manila, Manila, Philippines & 15 & 0.22 & 22 & 0.22 & 7 \\
\hline & 19 & Shen, Chienchiang & NRI of Chinese Medical Taiwan & 15 & 0.22 & 17 & 0.22 & 6 \\
\hline & 20 & Comi, Giancarlo & Univ Vita Salute San Raffaele, San Raffaele Sci Inst, Milan, Italy & 14 & 0.21 & 20 & 0.21 & 6 \\
\hline
\end{tabular}

TP - total papers; TC - total citations; ACP - average citation per papers; HI - $h$-index 
citations. The total number of citations comes from the Scopus database, which shows the total number of times a particular article has been cited by the journals listed in Scopus database. Among highly cited papers, the largest participation was seen from India (4 Papers), followed by China (2 papers), Morocco, US, Italy 1 papers each. "Methods for in vitro evaluating antimicrobial activity: A review” by Balouiri, M., Sadiki, M., Ibnsouda, S.K. is most cited 1679 citations published in the journal of Pharmaceutical Analysis of followed by "Chemistry and biological activities of flavonoids: An overview” by Kumar, S., Pandey, A.K. with 1427 citations published The Scientific World Journal, "Seeds: Ecology, biogeography, and, evolution of dormancy and germination" by Baskin, C.C., Baskin, J.M with 1131 citations published in Seeds: Ecology, Biogeography, and Evolution of Dormancy and Germination, "Cu and $\mathrm{Cu}$-Based Nanoparticles: Synthesis and Applications in Catalysis" by Gawande, M.B., Goswami, A., Felpin, F.-X., (...), Zboril, R., Varma, R.S. 1104 citations published in Chemical Reviews, "A review on plants extract

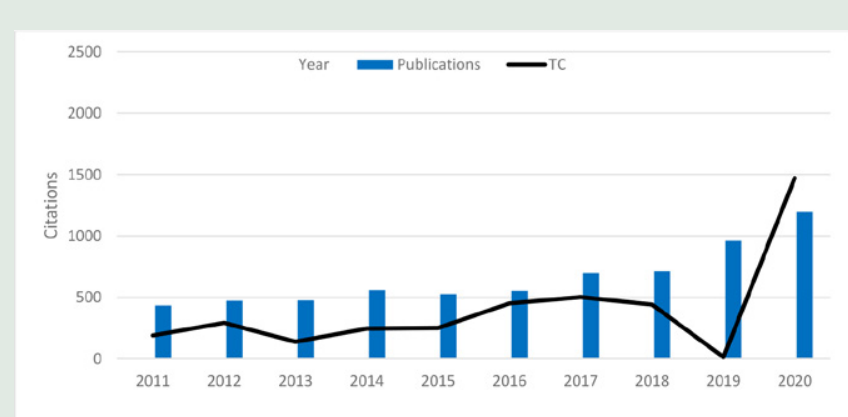

Figure 5: Highly cited citations and their citations by year. mediated synthesis of silver nanoparticles for antimicrobial applications: A green expertise" by Ahmed, S., Ahmad, M., Swami, B.L., Ikram, S. with 1091 citations published in Journal of Advanced Research. "Synthesis of metallic nanoparticles using plant extracts" by Mittal, A.K., Chisti, Y., Banerjee, U.C. with 1081 citations, published in Biotechnology Advance.

\section{Preferred Journals}

In this study, 160 journals were conformed to publish 6584 Calotropis research. Out of the 160 journals, 105 (1.59\%) and $103(1.56 \%)$ shared only two of those Calotropis research, and 5 journals (3.84\%) share,

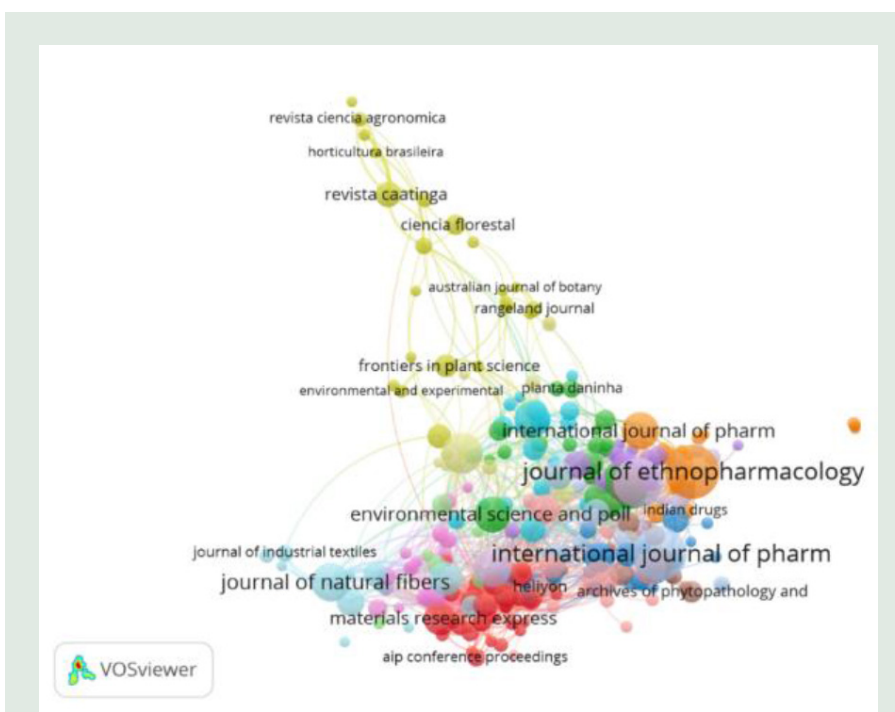

Figure 6: Most productive source in Calotropis research.

Table 7: Top 20 most productive source in Calotropis research.

\begin{tabular}{|c|c|c|c|c|c|c|c|c|}
\hline SN & Source & TP & $6584 \%$ & TC & $\boldsymbol{h}$ _index & g_index & m_index & PY_start \\
\hline 1 & Journal Of Ethnopharmacology & 105 & 1.59 & 3047 & 34 & 47 & 3.09 & 2011 \\
\hline 2 & International Journal Of Pharmacy And Pharmaceutical Sciences & 103 & 1.56 & 831 & 13 & 23 & 1.18 & 2011 \\
\hline 3 & Asian Journal Of Pharmaceutical And Clinical Research & 88 & 1.33 & 349 & 10 & 14 & 0.91 & 2011 \\
\hline 4 & International Journal Of Biological Macromolecules & 61 & 0.92 & 943 & 17 & 28 & 1.55 & 2011 \\
\hline 5 & Research Journal Of Pharmacy And Technology & 53 & 0.8 & 95 & 4 & 7 & 0.36 & 2011 \\
\hline 6 & Journal Of Natural Fibers & 52 & 0.79 & 281 & 10 & 14 & 1.25 & 2014 \\
\hline 7 & International Journal Of Pharma And Bio Sciences & 51 & 0.77 & 218 & 9 & 12 & 0.82 & 2011 \\
\hline 8 & International Journal Of Pharmaceutical Sciences Review And Research & 48 & 0.72 & 211 & 8 & 12 & 0.73 & 2011 \\
\hline 9 & Pakistan Journal Of Botany & 48 & 0.72 & 442 & 13 & 19 & 1.18 & 2011 \\
\hline 10 & Asian Pacific Journal Of Tropical Biomedicine & 47 & 0.71 & 968 & 17 & 29 & 1.55 & 2011 \\
\hline 11 & Environmental Science And Pollution Research & 47 & 0.71 & 950 & 16 & 29 & 1.45 & 2011 \\
\hline 12 & Industrial Crops And Products & 41 & 0.62 & 1029 & 16 & 31 & 1.78 & 2013 \\
\hline 13 & Journal Of Applied Pharmaceutical Science & 41 & 0.62 & 158 & 7 & 9 & 0.64 & 2011 \\
\hline 14 & Materials Research Express & 38 & 0.48 & 339 & 12 & 16 & 1.71 & 2015 \\
\hline 15 & Evidence-Based Complementary And Alternative Medicine & 37 & 0.56 & 809 & 14 & 28 & 1.27 & 2011 \\
\hline 16 & Plant Archives & 34 & 0.51 & 26 & 3 & 3 & 0.27 & 2011 \\
\hline 17 & Molecules & 32 & 0.48 & 625 & 13 & 24 & 1.18 & 2011 \\
\hline 18 & Parasitology Research & 32 & 0.48 & 1395 & 23 & 32 & 2.09 & 2011 \\
\hline 19 & Plos One & 31 & 0.47 & 455 & 14 & 19 & 1.40 & 2012 \\
\hline 20 & Scientific Reports & 31 & 0.47 & 403 & 12 & 19 & 1.50 & 2014 \\
\hline
\end{tabular}




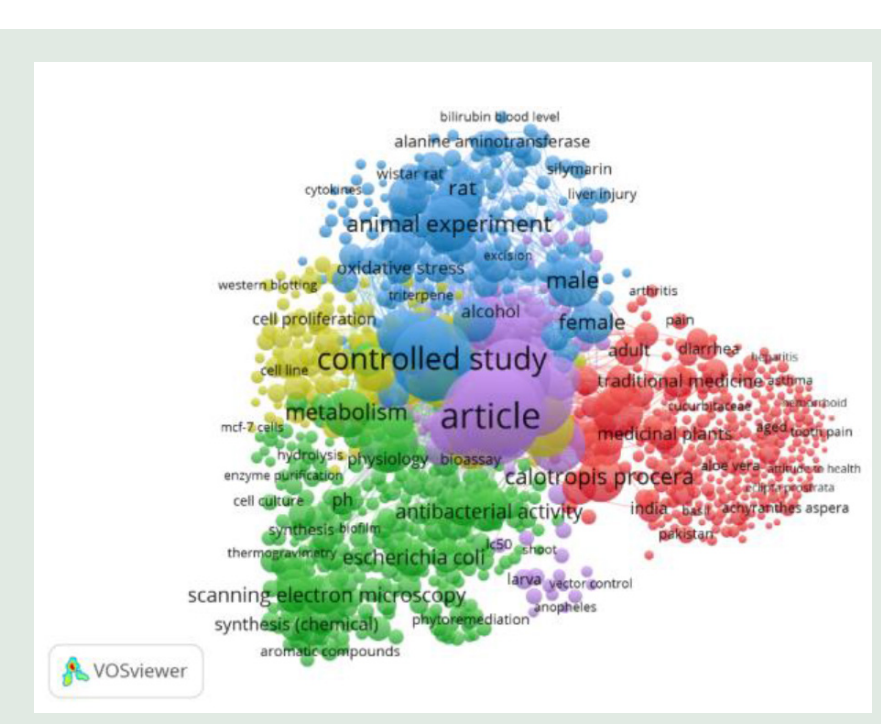

Figure 7: Significant keywords.
An increasing trend of publication growth and their corresponding citations over time signify the importance of this research topic. ${ }^{[21,22]}$ Among the leading countries India, China, Saudi Arabia, and Brazil dominated by the Institutions like King Saud University, Saudi Arabia, Universidade Federal do Ceara, Brazil, Ministry of Education China, China, Vellore Institute of Technology,

This study identifies prolific researchers, profound journals, predominating countries/institutions, forms for communicating, highly cited publications, significant keywords. The findings can act as a ready reference for researchers and serve them with useful information to formulate strategies for future studies. Researchers may find their peers and funding bodies could identify the targeted authors/institutions for possible investments.

\section{ACKNOWLEDGEMENT}

\section{Nil}

\section{Financial support and Sponsorship}

Nil.

\section{CONFLICT OF INTEREST}

The authors declare no conflicts of interest.

while 15 journals (7.55\%) share. Journal Of Ethnopharmacology was the most productive journal with 105 Calotropis research accounting for $1.59 \%$, followed closely by International Journal of Pharmacy and Pharmaceutical Sciences with 103 (1.56\%) both of which are the top journals in the category. The third most productive journal is Asian Journal of Pharmaceutical and Clinical Research with 88 (1.33\%), Table 7 and Figure 5 provides bibliometric details of the journal with highly cited articles (articles with 3074 citations) with $34 h$-index among the list; this retrieves the excellence of the journal ${ }^{[20]}$ and out of the 6584 papers, 1020 (14.54\%) appears in the top 20 list.

\section{Significant Keywords}

Around 168 significant keywords have been identified from the literature which throughout on the research trends in Calotropis research. Including on its Agricultural and Biological Sciences, Pharmacology, Toxicology and Pharmaceutics, Biochemistry, Genetics, and Molecular Biology and Medicine uses. These keywords are listed in Table in the decreasing orders of the frequency of their occurrence in the literature during the study period $2011-2020$.

\section{SUMMARY AND CONCLUSION}

Our analysis is based exclusively on the literature retrieved from Scopus in May 2021. And is solely based on the keywords appeared in the fields of the publications. The citation Figures may also vary across these databases. The findings of this study must hence be interpreted cautiously considering continues evaluation of research evidence on the topic. Among the different bibliometric approaches, we have used fractional counting to give equal weightage to the entities involved in research articles. Though equal weightage is an advantage of this approach. In this study, we have solely used the citation numbers for identifying influential articles, though we acknowledge that a normalized score citations using the journals impact factor and age of articles would have provided a different results.

We have preferred a bibliometric analysis of the global Calotropis literature published during the study period 2011 - 2020, as indexed in Scopus (as of May 2021). The study considered a total of 6,584 publications having 3,993 citations. Analysis was done using bibliometric parameters with Biblioshny and networks were visualized using VOSviewer.

\section{REFERENCES}

1. Rasool Hassan BA. Medicinal plants (importance and uses). Pharm Anal Acta. 2012;03(10):4172. doi: 10.4172/2153-2435.1000e139

2. Yudharaj $P$, Shankar M, Sowjanya $R$, Sireesha B, Naik EA, Priyadarshini RJ. Importance and uses of medicinal plants - an overview. Int J Preclin Pharm Res. 2016;7(2):67-73.

3. Dwivedi A, Chaturvedi M, Gupta A, Argal A. Medicinal utility of Calotropis procera (Ait.) R. Br. as used by natives of village Sanwer of Indore District, Madhya Pradesh. Int J Pharm Life Sci. 2010;1(3):188-90.

4. Kumar VL, Basu N. Anti-inflammatory activity of the latex of Calotropis procera. J Ethnopharmacol. 1994;44(2):123-5. doi: 10.1016/0378-8741(94)90078-7, PMID 7853863.

5. Asclepiadaceae RB. Chem Compos Leaf Stem Essent Oils Calotropis. $2011 ; 2(2): 255-60$.

6. Paul A, Kumar A. Review on Pharmocological properties of Aaka (Calotropis procera). Int J Econ Plants. 2018;5(3):157-62. doi: 10.23910/IJEP/2018.5.3.0261.

7. Ahmed KKM, B.M. Gupta G, N.K. Singh S, V.K. Thakur T, Kumar A. Celastrus paniculatus: A bibliometric assessment of Global publications output during 2001-18. Pharmacogn Rev. 2021;14(27):16-21. doi: 10.5530/phrev.2020.14.3.

8. B. M. Gupta G, K K Mueen Ahmed MA, Gupta R. Glycyrrhiza glabra (medicinal plant) research: A scientometric assessment of global publications output during 1997-2016. Pharmacogn J. 2018;10(6):1067-75. doi: 10.5530/pj.2018.6.180.

9. Ahmed KKM, B.M. Gupta G, Singh N, Kumar A. Global Research on Terminalia arjuna: A Quantitative and Qualitative Assessment of Publications during 2004-18. Pharmacogn Rev. 2021;14(27):45-52. doi: 10.5530/phrev.2020.14.8.

10. BM Gupta G, Ahmed KM. Moringa oleifera: A bibliometric analysis of India's publications during 1980-2019. J Young Pharm. 2020;12(3):207-14. doi: 10.5530/ jyp.2020.12.62.

11. Gupta B, Ahmed KM, Dhawan S, Gupta R. Aloe Vera (Medicinal Plant) Research: A Scientometric Assessment of Global Publications Output during 2007-16. Pharmacogn J. 2017;10(1):01-8. doi: 10.5530/pj.2018.1.1.

12. Garg KC, Kumar S, Bhatia VK, Ramasubramanian V, Kumar A, Kumari J. Plant genetics and breeding research: scientometric profile of selected countries with special reference to India. Ann Libr Inf Stud. 2011;58(2):184-97.

13. Dhawan SM. Phyllanthus emblica (medicinal plant) research: A scientometric assessment of global publications output during 2008-17. EC Pharmacol Toxicol. 2019;7(1):18-28:Article R, Gupta BM, Dhawan SM, Gupta R.

14. Gupta B, Mueen Ahmed K. Research on Nigella sativa: A scientometric assessment of global publications' output during 1989-2018. Int J Pharma Investig. 2018;8(4):173. doi: 10.4103/jphi.JPHI_10_19.

15. Gupta BM G, Ahmed KKM, Bansal J, Bansal M. Andrographis paniculata Global Publications Output: A Bibliometric Assessment during 2003-18. Int J Pharm Investig. 2019;9(3):101-8.

16. Chaman SM, Sedam MV, Bagalkoti VT. Scientometric study of Indian Hydrogel research based on Web of Science database. Libr Philos Pract (e- journal) [internet]; June. p. 1-17; 2021. Available from: https://digitalcommons.unl.edu/ libphilprac/5501 [cited 3/6/2021].

17. Chaman SM, Kumar, D, Biradar S. Medicine research in India: A scientometric assessment of publications during 2009-2018 [internet]; 2009. Available from: 
https://digitalcommons.unl.edu/libphilprac/2186 [cited 3/6/2021]

18. Cui Y. Global research landscape of high-level studies in geosciences based on highly cited papers. Curr Sci. 2020;118(4):532-42.

19. Kolle SR, Vijayashree MS, Shankarappa TH. Highly cited articles in malaria research: a bibliometric analysis. Collect Build. 2017;36(2):45-57. doi: 10.1108/ CB-10-2016-0028.
20. Chaman SM, Kappi M, Bagalkoti V, Biradar BS. Indian journal of marketing: A bibliometric analysis. Indian J Mark. 2020;50(4):55-64.

21. Chaman SM. Parashappa, Dharani Kumar P, Biradar BS. Marketing research in India: A scientometrics study. Webology. 2019 December 1;16(2):172-86.

22. Mallikarjun Kappi MB, Biradar B. Bibliometric analysis of Indian optics research: identifying knowledge domain. Libr Philos Pract. 2020 (September); 1.

Cite this article: Chaman SM, Kappi M, Ahmed KKM. Global Research Productivity on Calotropic sps. over the last Decade (2011 - 2020): A Bibliometric Evaluation. Pharmacog Res. 2021;13(3):113-20. 